\title{
HUBUNGAN PERILAKU DAN SANITASI LINGKUNGAN DENGAN PASIEN TB PARU
}

\author{
Maria Haryanti Butarbutar ${ }^{1}$ \\ 1.Akademi Keperawatan Helvetia Medan \\ *Email: maria_haryanthi@yahoo.com.au
}

\begin{abstract}
Abstrak
Penyakit Tuberkulosis (TB) adalah penyakit radang parenkim paru yang menular karena infeksi kuman TB yaitu Mikobakterium tuberkulosis (mycobacterium Tuberculosisi). Sebagian besar kuman TB menyerang paru tetapi dapat juga mengenai organ tubuh lain. Jenis penelitian yang digunakan penelitian survei analitik dengan menggunakan pendekatan cross sectional study. Penelitian dilakukan di wilayah kerja puskesmas Amplas Medan. Tehnik pengambilan sampel yang digunakan adalah purposive sampling sebanyak 41 orang. Instrumen penelitian menggunakan kuesioner, dengan menggunakan uji Chi Square. Hasil penelitian yang didapat hubungan perilaku dengan pasien TB paru adalah dengan BTA $(+)$ dan mempunyai perilaku positif sebanyak 22 orang $(53,6 \%)$ dengan Hasil uji square $0.001<\alpha 0.05$ yang artinya ada hubungan antara perilaku dengan pasien TB paru. Hubungan sanitasi lingkungang dengan TB paru adalah dengan sanitasi lingkungan kurang baik dengan BTA (-) sebanyak 15 orang (36,5\%). Hasil uji chi- square 0,008 $<\alpha 0,05$ maka dapat disimpulkan ada hubungan yang signifikan antara sanitasi lingkungan dengan pasien TB paru di daerah wilayah kerja Puskesmas Amplas Medan. Disarankan agar masyarakat lebih memperhatikan keadaan lingkungan rumah dan sekitarnya dan menambah pengetahuan dengan cara sering membaca dan menjaga kesehatan agar terhindar dari infeksi kuman Mikobakterium tuberculosis.
\end{abstract}

Kata Kunci: Perilaku, Sanitasi Lingkungan, pasien TB Paru

\begin{abstract}
Relationship of Behaviour and Environmental Sanitation with TB Patients. Tuberculosis (TB) is an inflammatory parenchymal lung disease that is contagious due to infection of TB bacteria named Micro bacteria tuberculosis (mycobacterium Tuberculosis). Most TB germs attack the lungs but can also affect other organs. The type of research used analytic survey research using cross sectional study approach. The research was conducted in the working area of Medan Amplas Community Health Center. The sampling technique used is purposive sampling as many as 41 people. The research instrument using questionnaire, using Chi Square test. The result of this research is the correlation between the behavior with the pulmonary tuberculosis patients with BTA (+) and has positive behavior as many as 22 people $(53,6 \%)$ with result of square test $0.001<\alpha 0.05$ which means there is the relationship between behavior and pulmonary TB patients. The relationship of sanitation with pulmonary tuberculosis is poorly environmental sanitation with BTA (-) as many as 15 people (36.5\%). The chi-square test $0,008<\alpha 0,05$ can be concluded that there is significant correlation between environmental sanitation with pulmonary tuberculosis patient in working area of Puskesmas Amplas Medan. It is suggested that people pay more attention to the environment of the home and surrounding areas and increase their knowledge by reading and maintaining health frequently to prevent from the infection of Mycobacterium tuberculosis bacteria.
\end{abstract}

Keywords, Behavior, Environmental Sanitation, Pulmonary TB patients 


\section{Pendahuluan}

Pembangunan kesehatan menuju Indonesia sehat (2015 - 2025) bertujuan untuk meningkatkan kesadaran, kemauan dan kemampuan hidup bagi setiap orang agar terwujud derajat kesehatan masyarakat yang optimal, sehingga banyak program yang telah di rencanakan dan ditetapkan oleh pemerintah untuk membangun Indonesia sehat. Salah satunya yaitu mengeksekusi penyakit akibat infeksi pernafasan yaitu TB paru, pernafasan sangatlah berbahaya jika mengalami gangguan, dampaknya akan mengalami gagal nafas. Pertolongan sangatlah penting bagi pasien yang gagal nafas, sehingga pernafasan disebut harus dijaga agar pasien tetap melakukan inhalasi dan ekhalasi dengan baik. Agar tidak terjadi komplikasi yang berlanjut maka diperlukan pertolongan pada tuberculosis dan ini bisa menjadi pertolongan kegawat daruratan nantinya jika tidak di tanggulangi secara dini.

Tuberkulosis adalah penyakit saluran nafas yang disebabkan oleh mycobacterium, yang berkembang biak di dalam bagian tubuh dimana terdapat banyak aliran darah dan oksigen. Infeksi bakteri ini biasanya menyebar melewati pembuluh darah dan kelenjar getah bening, tetapi secara utama menyerang paru-paru. Bakteri TB membunuh jaringan dari organ yang terinfeksi dan membuatnya sebagai kondisi yang mengancam nyawa jika tidak dilakukan terapi (Pasipanodya, et al. 2011).

Penyakit Tuberkulosis (TB) adalah penyakit radang parenkim paru yang menular karena infeksi kuman TB yaitu Mikobakterium tuberkulosisi. Sebagian besar kuman TB menyerang paru tetapi dapat juga mengenai organ tubuh lain Depkes, 2008).

Penyakit Tuberculosis (TB) adalah penyakit yang sudah ada sedari zaman purbakala, terbukti dari penemuanpenemuan kuno, penggalian arkeologis di Mesir menemukan sisa-sisa tulang belakang manusia dengan tanda-tanda khas TB tulang belakang, kira-kira tahun 3700 SM, ditemukan mumi dari sekitar 100 SM dengan ciri-ciri khas penyakit TB paru. Khususnya untuk Indonesia, pada saat Candi Borobudur didirikan (abad VIII) saat itu TB sudah menjadi penyakit rakyat, sehingga pemahat mengambil contoh orang sakit yang bertemu dengan Pangeran Sidharta Gautama. Orang tersebut kurus dengan bahu tertarik ke atas dan tulangtulang iganya menonjol keluar, sehingga sering menunjukkan gejala umum TB yaitu batuk, batu darah dan badan mengurus (Danusantosa, 2014). 
Di Amerika Serikat pada tahun 1915, masih dianut paham bahwa penularan TB adalah melalui kebiasaan meludah di sembarangan tempat dan ditularkan melalui debu dan lalat. Di Negara maju seperti Eopa Barat dan Amerika Utara, angka kesakitan maupun angka kematian TB paru pernah menurun.

Di Amerika Utara, saat awal orang Eropa berbondong-bondong bermigrasi. Kematian akibat TB pada tahun 1800 sebesar 650 per 100.000 penduduk, tahun 1860 turun menjadi 400 per 100.000. Angka kematian karena tuberculosis di Amerika Serikat pada tahun 1976 telah turun menjadi 1.4 per 100.000 penduduk. Akan tetapi pertengahan 1980-an kesakitan TB paru di Amerika Utara maupun Eropa Barat meningkat dan bahkan semakin sulit dan tidak mempan untuk melawannya. Pada tahun 1992, angka kematian TB menjadi 6.2 per 100.00 penduduk (naik hampir 5 kali dibandingkan angka kematian tahun 1976 yang hanya 1.4 per 100.000 penduduk, Pada tahun 1995, diperkirakan ada 9 juta pasien TB baru dan 3 juta kematian akibat TB di seluruh dunia. Diperkirakan 95\% kasus TB dan 98\% kematian akibat TB di dunia, terjadi di Negara-negara berkembang (Depkes RI, 2004).
Sekitar $75 \%$ pasien TB adalah kelompok usia yang paling produktif secara ekonomis (25-50 tahun). Diperkirakan seorang pasien TB dewasa, akan kehilangan rata-rata waktu kerjanya 3-4 bulan dan berakibat kehilangan pendapatan keluarga. Selain itu merugikan secara ekonomis, TB juga memberikan dampak buruk lainnya secara social, stigma bahkan dikucilkan oleh masyarakat (Djojodibroto, 2015). Indonesia salah satu Negara berkembang yang menempati peringkat ke4 kasus TB tertinggi di dunia. Di Indonesia, TB merupakan masalah utama kesehatan masyarakat. Jumlah pasien TB di Indonesia merupakan ke-3 terbanyak setelah India dan Cina dengan jumlah pasien sekitar $10 \%$ dari total jumlah pasien TB di dunia. Jumlah penderita TB paru di Indonesia secara nasional pada tahun 2010 adalah sekitar 302.861 orang, dimana 183.366 kasus diantaranya adalah menderita BTA (+). Angka ini cenderung mengalami peningkatan dibandingkan dengan jumlah penderita TB paru BTA (+) tahun 2008 sebesar 161.741 kasus. Masih tingginya angka penyakit TB paru di Indonesia dipengaruhi oleh beberapa factor antara lain diantaranya rendahnya penghasilan, tingkat kepadatan penduduk, tingkat pendidikan serta rendahnya kesehatan pada masyarakat (Depkes, 2002). 
Prevalensi TB paru paling banyak terdapat pada jenis kelamin laki-laki 819 per 100.000 penduduk. Penduduk yang bertempat tinggal di desa 750 per 100.000 penduduk, kelompok pendidikan yang tidak sekolah 1.041 per 100.000 penduduk. Petani/pelayan/buruh 858 per 100.000 penduduk dan pada penduduk dengan tingkat pengeluaran kuintil 4 sebesar 607 per 100.000 penduduk (Kementerian Kesehatan RI, 2011).

Berdasarkan laporan WHO dalam Global Tuberculosis Report 2014, Indonesia menempati urutan kelima terbesar di dunia sebagai penyumbang penderita TB setelah negara India, Cina, Nigeria, dan Pakistan. Tingkat resiko terkena penyakit TB di Indonesia berkisar antara $1,7 \%$ hingga $4,4 \%$. Secara nasional, TB dapat membunuh sekitar 67.000 orang setiap tahun, setiap hari 183 orang meninggal akibat penyakit TB di Indonesia (Dinas Kesehatan Kota Medan, 2014).

Kesehatan perumahan adalah kondisi fisik, kimia dan biologic di dalam rumah di lingkungan rumah dan perumahan sehingga memungkinkan penghuni atau masyarakat memperoleh derajat kesehatan yang optimal Kesehatan perumahan adalah kondisi fisik.

Majelis Perserikatan Bangsabangsa (PBB) telah menetapkan 2008 sebagai tahun sanitasi lingkungan Internasional. Hal ini disebabkan masih terdapat sebanyak 2.6 milyar manusia di dunia berkembang belum menikmati sanitasi, hasilnya tiap anak meninggal setiap tahun karena hasil yang sesungguhnya dapat dicegah. PBB menganggap sanitasi vital untuk kesehatan, berpengaruh pasa aspek ekonomi karena sanitasi yang lebih baik berdampak positif pada pengurangan kemiskinan, sanitasi berkontribusi positif pada pembangunan social, mengurangi penyakit, meningkatkan gizi, meningkatkan daya tangkap anak di sekolah serta meningkatkan produktifitas kerja orang dewasa.

Sanitasi tidak hanya mencakup sanitasi dasar seperti jamban, penyediaan air bersih, tempat pembuangan sampah dan saluran air limbah saja. Namun meliputi ventilasi, kelembaban udara, kepadatan hunian. Dengan terjaga kondisi sanitasi baik ditempat umum terutama di rumah sendiri maka kemungkinan resiko terjadi penyebaran penyakit dapat dicegah (Dinas Kesehatan Kota Medan. 2006).

Kasus TB Paru di Kota Medan tahun 2013 secara klinis terjadi peningkatan dari tahun 2012. Angka penemuan TB pada tahun 2012 yaitu sebesar 21.079 kasus dengan 3.037 kasus TB Paru BTA (+), 
sedangkan pada tahun 2013 ditemukan sebesar 26.330 kasus dengan 2.894 kasus TB Paru BTA (+) dimana seluruhnya mendapatkan penanganan pengobatan dengan kesembuhan 2.163 orang $(74,74 \%)$ serta angka keberhasilan pengobatan sebesar 79,03\%. Selain itu, dari 39 puskesmas yang ada di Kota Medan terdapat 1.729 penderita TB Paru BTA (+). Dari 1.729 penderita TB Paru BTA (+) sebanyak 1.616 penderita $(87,67 \%)$ diberikan pengobatan.

Dari data Dinas Kesehatan Kota Medan tahun 2014, angka kesembuhan penderita TB Paru terendah terdapat di Puskesmas Desa Lalang. Jumlah penderita TB Paru BTA (+) yang diobati di Puskesmas tersebut pada tahun 2014 sebanyak 42 penderita. Dari 42 penderita, jumlah penderita yang dinyatakan sembuh hanya 25 penderita $(59,52 \%)$. Hal ini menunjukkan angka kesembuhan penderita TB belum mencapai target yang ditetapkan yaitu sebesar $85 \%$. Sedangkan angka penemuan kasus di Puskesmas Desa lalang pada tahun 2013 sekitar 92 kasus dengan BTA (+) sebesar 23 kasus (Dinas Kesehatan Kota Medan, 2014).

Hasil penelitian lainnya, Nukman Permatasari, faktor yang memengaruhi keberhasilan TB paru adalah: a) faktor sarana yang meliputi tersedianya obat yang cukup dan kontiniu, edukasi petugas kesehatan, dan pemberian obat yang adekuat, b) faktor penderita yang meliputi pengetahuan, kesadaran dan tekad untuk sembuh, dan kebersihan diri, c) faktor keluarga dan lingkungan masyarakat.

Kasus TB Paru masih banyak sekali ditemukan di Sumatera Utara, dari survey yang dilakukan di setiap puskesmas masih saja ada masyarakat yang terkena kasus TB Paru. Tujuan Penelitian ini untuk mengetahui hubungan perilaku dan sanitasi lingkungan dengan pasien TB paru di Puskesmas Glugur Darat Medan.

\section{Metode}

Jenis penelitian yang digunakan merupakan penelitian survei analitik dengan menggunakan pendekatan Cross sectional study (potong lintang). Penelitian dilakukan di wilayah kerja puskesmas Amplas Medan. Jumlah populasi 107 orang yang terkena TB Paru, tehnik pengabilan sampel yang digunakan adalah purposive sampling sebanyak 41 orang. Instrumen penelitian menggunakan kuesioner.

Metode pengumpulan data dibagi menjadi 2 yaitu data primer, yang dikumpulkan secara langsung dari jawaban responden melalui kuesioner dan data sekunder yaitu data yang diperoleh dari 
pihak Dinas Kesehatan dan Puskesmas Amplas tentang hubungan perilaku dan sanitasi lingkungan dengan pasien TB paru. Adapun analisa yang digunakan adalah analisis bivariat dengan menggunakan uji Chi Square.

\begin{tabular}{|l|} 
V. Dependen \\
$\begin{array}{l}\text { - Perilaku } \\
\text { - Sanitasi } \\
\text { Lingkungan }\end{array}$
\end{tabular}$\longrightarrow$\begin{tabular}{c|} 
V. Independen \\
Pasien TB \\
Paru \\
\hline
\end{tabular}

\section{Hasil}

Berdasarkan penelitian yang telah dilakukan di wilayah kerja Puskesmas Amplas Medan didapatkan hasil adalah sebagai berikut:

Table 1. Distribusi Frekuensi berdasarkan jenis kelamin, umur, pendidikan

\begin{tabular}{|c|c|c|c|}
\hline No & $\begin{array}{c}\text { Kategori } \\
\text { Responden }\end{array}$ & Frekuansi & $\%$ \\
\hline \multicolumn{4}{|c|}{ Umur } \\
\hline 1 & $11-20$ & 5 & 12,2 \\
\hline 2 & $21-30$ & 12 & 29,3 \\
\hline 3 & $31-60$ & 22 & 53,6 \\
\hline 4 & $>60$ & 2 & 4,9 \\
\hline \multicolumn{4}{|c|}{ Jenis Kelamin } \\
\hline 1 & Laki-laki & 25 & 61.0 \\
\hline 2 & Perempuan & 16 & 39.0 \\
\hline \multicolumn{4}{|c|}{ Pendidikan } \\
\hline 1 & SD & 3 & 7.3 \\
\hline 2 & SMP & 8 & 19.5 \\
\hline 3 & SMA & 27 & 65.9 \\
\hline 4 & P. Tinggi & 3 & 7.3 \\
\hline \multicolumn{4}{|c|}{ Status } \\
\hline \multicolumn{4}{|c|}{ Perkawinan } \\
\hline 1 & Kawin & 35 & 85.3 \\
\hline 2 & Tidak kawin & 6 & 14.7 \\
\hline \multicolumn{4}{|c|}{ Perilaku } \\
\hline 1 & Positif & 23 & 56,1 \\
\hline 2 & Negatif & 18 & 43.9 \\
\hline \multicolumn{4}{|c|}{ Sanitasi } \\
\hline \multicolumn{4}{|c|}{ lingkungan } \\
\hline 1 & Baik & 31 & 75.6 \\
\hline 2 & Kurang baik & 10 & 24.4 \\
\hline
\end{tabular}

Berdasarkan table 1. Diatas diketahui bahwa dari 41 orang responden yang diteliti, distribusi responden menurut kelompok umur yang terbanyak yaitu berada pada usia produktif yaitu dewasa pertengahan (31-60 tahun) berjumlah 22 orang $(53,6 \%)$. Pada jenis kelamin diketahui laki-laki 25 orang (61.0\%), berdasarkan pendidikan SMA sebanyak 27 orang $(65.9 \%)$, status pernikahan kawin sebanyak 35 orang (85.3) dengan perilaku positif sebanyak 23 orang $(56,1 \%)$ dan sanitasi lingkungan baik sebanyak 31 orang $(75,6 \%)$.

\section{Analisa Bivariat}

Berdasarkan pengolahan data dengan bantuan penghitungan statistik melalui komputer diperoleh hasil penghitungan yang dapat dilihat pada tabel 4 sebagai berikut:

Tabel. 2 Hubungan Perilaku dengan Pasien TB paru di Wilayah Kerja Puskesmas Amplas Medan

\begin{tabular}{|c|c|c|c|c|c|c|c|}
\hline \multirow{3}{*}{$\begin{array}{c}\text { Perilak } \\
\mathbf{u}\end{array}$} & \multicolumn{4}{|c|}{ Pasien TB Paru } & \multirow{3}{*}{$\mathbf{N}$} & \multirow{3}{*}{$\%$} & \multirow{3}{*}{$p-v$} \\
\hline & \multicolumn{2}{|c|}{ BTA (+) } & \multicolumn{2}{|c|}{ BTA (-) } & & & \\
\hline & $\mathbf{n}$ & $\%$ & $\mathbf{n}$ & $\%$ & & & \\
\hline Positif & 22 & 53,6 & 1 & 2.4 & 23 & 56 & \\
\hline Negatif & 9 & 21.8 & 9 & 22,0 & 18 & 43.8 &, 001 \\
\hline Jumlah & 31 & 75,6 & 10 & 24,4 & 41 & 100 & \\
\hline
\end{tabular}

Table 2. menunjukkan bahwa hubungan pasien TB paru BTA (+) dengan perilaku positif sebanyak 22 orang $(53,6 \%)$ dan perilaku negatif sebanyak 9 orang 
$(21,8 \%)$ dan pasien TB paru BTA (-) dengan perilaku positif sebanyak 1 orang $(2,4 \%)$, perilaku negative sebanyak 9 orang $(22,0 \%)$ dengan Hasil uji square yang didapat $p$-value $0.001<\alpha 0.05$.

Table 3. Hubungan Sanitasi Lingkungan dengan pasien TB paru di Wilayah Kerja Puskesmas Amplas Medan

\begin{tabular}{|c|c|c|c|c|c|c|c|}
\hline \multirow{3}{*}{$\begin{array}{c}\text { Sanitas } \\
\text { i } \\
\text { lingk } \\
\end{array}$} & \multicolumn{4}{|c|}{ Pasien TB Paru } & \multirow{3}{*}{$\mathbf{N}$} & \multirow{3}{*}{$\%$} & \multirow{3}{*}{$p-v$} \\
\hline & \multicolumn{2}{|c|}{ BTA (+) } & \multicolumn{2}{|c|}{ BTA (-) } & & & \\
\hline & $\mathbf{n}$ & $\%$ & $\mathbf{n}$ & $\%$ & & & \\
\hline Baik & 8 & 19.5 & 16 & 39 & 24 & 58,5 & ,008 \\
\hline $\begin{array}{c}\text { Kurang } \\
\text { baik }\end{array}$ & 2 & 4,87 & 15 & 36,5 & 17 & 41,5 & \\
\hline Jumlah & 10 & 24.3 & 31 & 75,5 & 41 & 100 & \\
\hline
\end{tabular}

Tabel 3. menunjukkan bahwa hubungan pasien TB paru (+) dengan sanitasi lingkungan baik sebanyak 8 orang $(19,5 \%)$ kurang baik sebanyak 2 orang (4,87\%). Pasien TB paru BTA (-) dengan sanitasi lingkungan baik sebanyak 8 orang (19.5\%) dan sanitasi lingkungan kurang baik dengan BTA (-) sebanyak 15 orang $(36,5 \%)$. Hasil uji square yang didapat dapat p-value $0,008<\alpha 0,05$ maka dapat disimpulkan ada hubungan yang signifikan antara sanitasi lingkungan dengan pasien TB paru di daerah wilayah kerja Puskesmas Amplas Medan.

\section{Pembahasan}

\section{Distribusi Frekuensi berdasarkan karakteristik}

Hasil penelitian yang dilakukan terhadap 41 orang responden diperoleh bahwa umur responden 11 - 30 tahun sebanyak 17 orang $(41,4 \%)$ responden 31 60 tahun sebanyak 24 orang $(58,5 \%)$, ini menunjukkan hal tersebut sejalan dengan pernyataan Hardywinoto (2007) yang mengatakan bahwa semakin tua umur seseorang maka semakin banyak masalah organ tubuh yang mengalami gangguan atau masalah yang berdampak pada kebutuhan akan pemeliharaan kesehatannya.

Pada gambaran distribusi frekuensi menurut jenis kelamin hasil penelitian tersebut menunjukkan laki-laki 25 orang $(61,0 \%)$ dan perempuan 16 orang $(39,0 \%)$ Pada penderita TB Paru lebih banyak terjadi pada laki-laki daripada wanita berhubungan dengan hormonal pada wanita yang produktif, dimana hormon estrogen mempunyai peranan penting pelindung.

Berdasarkan hasil penelitian menurut pendidikan dari pendidikan SD sampai SMP sebanyak 11 orang $(26,8 \%)$ dan SMA sampai perguruan tinggi sebanyak 30 orang $(73,2 \%)$. sejalan dengan pernyataan Hardywinoto (2007) semakin tinggi pendidikan maka kebutuhan dan tuntutan terhadap pelayanan kesehatan semakin meningkat pula, semakin rendah tingkat pendidikan ini akan mengakibatkan 
mereka sulit menerima penyuluhan yang diberikan oleh tenaga penyuluh.

Berdasarkan status pernikahan menikah 35 orang $(85,3 \%)$ dan tidak menikah sebanyak 6 orang $(14,7 \%)$. Sejalan dengan penelitian yang dilakukan oleh Rusnoto (2008) yang mengatakan bahwa diketahui bahwa proporsi adanya riwayat penyakit yang menyertai pada kelompok penderita 32,1\% lebih besar dari kelompok bukan penderita ( 0 \% dikarenakan adanya penularan, dari suami ke istri.

\section{Bivariat}

Berdasarkan penelitian yang telah dilakukan berdasarkan perilaku, ditemukan hasil perilaku yang positif sebanyak 23 orang $(56.1 \%)$, perilaku yang negatif sebanyak 18 orang (43.9\%). Hubungan perilaku positif dengan pasien TB paru BTA (+) 22 orang $(53.6 \%)$ dan perilaku negative dengan BTA (+) sebanyak 9 orang $(21,8 \%)$ dan perilaku positif dengan pasien TB paru BTA (-) 1 orang $(2,4 \%)$ dengan perilaku negative dengan pasien TB paru BTA (-) sebanyak 9 orang $(22,0 \%)$ dengan p-value $0.001>\alpha 0.05$ yang artinya ada hubungan antara perilaku dengan pasien TB paru.

Sejalan dengan penelitian yang dilakukan menurut Skinner dalam
Notoadmojo mengatakan bahwa perilaku adalah merupakan respon atau reaksi seseorang terhadap stimulus (rangsangan dari luar). Perilaku dalam penelitian ini adalah tindakan atau kebiasaan yang biasa dilakukan oleh responden terhadap pencegahan penularan infeksi tersebut.

Berdasarkan penelitian yang telah dilakukan pasien TB paru BTA (+) dengan sanitasi lingkungan baik sebanyak 8 orang (19.5\%) dan sanitasi lingkungan kurang baik sebanyak 2 orang $(4,87 \%)$. Begitu juga pasien TB paru BTA (-) dengan saitasi lingkungan baik sebanyak 16 orang (39\%) dan kurang baik sebanyak 15 orang (36,5\%). Dengan hasil chi-square 0,008, yang artinya ada hubungan yang signifikan antara pasien TB paru dengan sanitasi lingkungan.

Sehingga dengan demikian dapat diambil kesimpulan bahwa terdapat hubungan yang berarti / bermakna antara sanitasi lingkungan dengan pasien TB Paru, taraf signifikansi dari hasil analisa 0,008 menunjukkan bahwa hasil yang didapatkan untuk mengetahui antara sanitasi lingkungan dengan pasien TB Paru sangat signifikan. hal ini menunjukkan adanya hubungan yang kuat antara sanitasi lingkungan dengan pasien TB Paru. Arah hubungannya adalah positif antara sanitasi lingkungan dan pasien TB Paru yaitu 
semakin baik tingkat sanitasi lingkungan semakin rendah pasien TB Paru.

Menurut Ahmadi (2008), faktor lingkungan (kepadatan, lantai rumah, ventilasi, dll) merupakan faktor risiko yang berperan terhadap timbulnya penyakit $\mathrm{Tb}$ paru, di samping faktor kependudukan (jenis kelamin, umur, status gizi, sosial ekonomi). Kondisi rumah yang baik penting untuk mewujudkan masyarakat yang sehat. Rumah dikatakan sehat apabila memenuhi persyaratan empat hal pokok antara lain; memenuhi kebutuhan fisiologis seperti pencahayaan, penghawaan, ruang gerak yang cukup dan terhindar dari kebisingan yang mengganggu, memenuhi kebutuhan psikologis seperti "Privacy" yang cukup dan komunikasi yang baik antar penghuni rumah, memenuhi persyaratan pencegahan penyakit menular yang meliputi penyediaan air bersih, pembuangan tinja dan air limbah rumah tangga, bebas dari vektor penyakit dan tikus, kepadatan hunian yang tidak berlebihan, sinar matahari yang cukup, makanan dan minuman yang terlindung dan pencemaran serta pencahayaan dan penghawaan yang cukup serta memenuhi persyaratan pencegahan terjadinya kecelakaan baik yang berasal dari dalam maupun dari luar rumah menurut peraturan Kep Men Kes RI No. 829, 1999. Menurut
Tjandra Yoga (2007) mengatakan bahwa TB dapat menular yang tinggal di rumah padat, kurang sinar matahari dan sirkulasinya buruk atau lembab karena bakteri Mycobacterium Tuberculosis akan dapat menetap lama dan berkembang biak tetapi jikalau banyak udara dan yang terutama sinar matahari dan sirkulasi, ventilasi baik bakteri itu tidak akan bertahan lama sekitar $1-2$ jam.

Didukung juga oleh Chandra (2006) yang mengatakan kepadatan hunian erat kaitan dengan factor social ekonomi seseorang, karena kepadatan kecil membuat orang tidak dapat hidup layak yang memenuhi syarat - syarat kesehatan. Price \& Wilson (2006). Standart untuk perumahan umum pada dasarnya ditujukan untuk menyediakan rumah tinggal yang cukup baik dalam bentuk desain, letak dan luas ruangan, serta vasilitas lainnya agar dapat memenuhi kebutuhan keluarga atau dapat memenuhi kebutuhan keluarga atau dapat memenuhi persyaratan rumah tinggal yang sehat dan menyenangkan. Rumah atau tempat tinggal yang buruk atau kumuh dapat mendukung terjadinya penularan penyalit dan gangguan kesehatan seperti TB paru. 


\section{Kesimpulan}

Dalam penelitian ini dapat disimpulkan bahwa:

1. Berdasarkan umur $11-20$ tahun sebanyak 5 orang $(12,2 \%), 21-30$ tahun sebanyak 12 orang $(29,3 \%), 31$ 60 tahun sebanyak 22 orang $(53,6 \%)$, $>60$ tahun sebanyak 2 orang $(4,9 \%)$.

2. Berdasarkan jenis kelamin, laki - laki sebanyak 25 orang (61\%) dan perempuan 16 orang (39\%)

3. Berdasarkan pendidikan, SD sebanyak 3 orang $(7,3 \%)$, SMP sebanyak 8 orang $(19,5 \%)$, SMA sebanyak 27 orang $(65,9 \%)$ dan Perguruan Tinggi 3 orang $(7,3 \%)$

4. Berdasarkan status perkawinan, yang kawin sebanyak 35 orang $(85,3 \%)$ dan tidak kawin 6 orang $(14,7 \%)$.

5. Berdasarkan prilaku diperoleh, yang berprilaku positif sebanyak 23 orang $(56,1 \%)$ dan perilaku negative sebanyak 18 orang $(43,9 \%)$

6. Berdasarkan sanitasi lingkungan diperoleh hasil, sanitasi baik sebanyak 31 orang $(75,6 \%)$ dan sanitasi lingkungan kurang baik sebanyak 10 orang $(24,4 \%)$

7. Hasil penelitian yang diperoleh berdasarkan 2 variabel antara perilaku dengan pasien TB paru adalah dengan hasil chi-square 0.001

8. Hasil penelitian yang diperoleh berdasarkan 2 variabel antara sanitasi lingkungan dengan pasien TB paru dengan hasil chi-square 0.008 .

\section{Referensi}

Ahmadi, U F. (2005). Manajemen Penyakit Berbasis Wilayah, Jakarta: Penerbit Buku Kompas. https://media.neliti.com/media/publ ications/39821-ID-manajemenpenyakit-berbasis-wilayah.

Chandra. B, (2006). Pengantar Kesehatan Lingkungan. Jakarta: EGC

Data

Dinas

Perumahan. http://data.jakarta.go.id/organizatio $\mathrm{n} /$ dinas-perumahan-dan-gedungpemda

Darmanto Djojodibroto. (2015), Respirologi (Respiratory Medicine), ed.2, Buku Kedokteran EGC.

Depkes RI, Ditjen PP dan PL. (2008). Pedoman Nasional Penanggulangan Tuberkulosis dan Starndart Internasional Untuk Pelayanan Tuberkulosis

Depkes RI, Laporan Hasil Ditjen PP dan PL. (2004). Survey Hasil 
Implementasi Program Nasional Penanggulangan TB di Daerah ICDC

Departemen kesehatan (Depkes). (2002). Pedoman nasional penanggulangan tuberculosis di Indonesia. Edisi ke7. Kementrian Kesehatan RI, JakartaIndonesia

Dinas Kesehatan Kota Medan. (2014). Profil Dinas Kesehatan Kota Medan. dinkes. pemkomedan.go.id/hal-profildinas-kesehatan.htm

Dinas Kesehatan Kota Medan. (2006). Syarat Rumah Sehat untuk Penderita Penyakit TBC, Jakarta.

Halim Danusantosa. (2014). Buku Saku Ilmu Penyakit Paru ed.2, Penerbit Buku Kedokteran EGC

Hardywinoto, S. (2007). Panduan gerontologi. Jakarta: Pustaka utama Kementerian Kesehatan RI. (2011). Riset Kesehatan Dasar 2010. Jakarta Notoatmodjo, Soekidjo. (2007). Promosi Kesehatan dan Ilmu perilaku. Jakarta: Rineka Cipta.
Permatasari, A. (2005). Pemberantasan Penyakit TB Paru dan Strategi DOTS. Bagian Paru. FK USU. Medan.

Rusnoto. (2008). Faktor - Faktor yang Berhubungan dengan Kejadian TB Paru pada Usia Dewasa, Surabaya, Undip, http://eprints.undip.ac.id/5283/1/Ru snoto.pdf

Pasipanodya J, et al. (2011). "Tuberculosis and Other Mycobacterial Diseases." Conn's Current Therapy.

Price SA, Wilson LM. (2006). Patofisiologi konsep klinis proses-proses penyakit, alih bahasa Pendit BU, et. al. editor edisi bahasa Indonesia, Hartanto H. Ed 6. Vol 2. Jakarta. EGC; 2004: 853-857

Tjandra Yoga. (2007). Diagnosis TB pada anal lebih sulit, Mediakom Info Sehat untuk Semua Departemen Kesehatan RI. https://media.neliti.com/media/publ ications/75991-ID-prevalensipenyakit-tuberculosis-paru 